\title{
AN ANALYSIS OF THE LOAD-BEARING CAPACITY OF TIMBER-CONCRETE COMPOSITE BEAMS WITH PROFILED SHEETING
}

\author{
Maciej SZUMIGAŁA, Ewa SZUMIGAŁA, Łukasz POLUS ${ }^{1}$ \\ Poznan University of Technology, Poznań, Poland
}

\begin{abstract}
This paper presents an analysis of timber-concrete composite beams. Said composite beams consist of rectangular timber beams and concrete slabs poured into the steel sheeting. The concrete slab is connected with the timber beam using special shear connectors. The authors of this article are trying to patent these connectors. The article contains results from a numerical analysis. It is demonstrated that the type of steel sheeting used as a lost formwork has an influence on the load-bearing capacity and stiffness of the timber-concrete composite beams.
\end{abstract}

Keywords: composite timber-concrete structures, composite beams, FEM, Abaqus

\section{INTRODUCTION}

Wood has been used as a building material for thousands of years. After a period of stagnation, this material has recently been often used for structural elements and is very competitive in the construction market. All building materials have improved. The use of high-performance concrete is one of the newest trends in concrete structures $[1,8,16]$. There are new types of reinforcement such as basalt fibre-reinforced polymer bars [21]. Designers have started using high performance steel with a strength of more than $460 \mathrm{MPa}$ [9] for steel structures. They also use steel thin-walled structures [3, 4, 27] or aluminium structures [29], because of their lightness (tendency to design light- weight structures). Despite

\footnotetext{
${ }^{1}$ Corresponding author: Poznan University of Technology, Faculty of Civil and Environmental Engineering, Institute of Structural Engineering, ul. Piotrowo 5, 60-965 Poznań, Poland, e-mail: lukasz.polus@put.poznan.pl, tel. +48616652098
} 
the significant development of other building materials, wood is still used and has also developed. Glued-laminated timber is used for long-span structures, because it permits the creation of structural members much larger than trees [18]. However, it is combustible material. The cross-section area of the timber beam is large and the rate of charting of the beam's surfaces is slow. For this reason, glued-laminated timber exposed to fire can carry loads substantially longer than unprotected steel. The fire and flame spread resistance of glued-laminated timber can be enhanced through the application of fire-resistant surface coatings or pressure impregnation with fire retardants. The durability of glued-laminated timber depends on the types of timber, glue, preservative and application method. One instance where glued-laminated timber is chosen for its durability is in swimming pool roofs - this is a particularly corrosive environment with high humidity and chlorine levels and glued-laminated timber provides a durable lowmaintenance solution. Glued-laminated timber may be also used for bridges, roof systems for single-story warehouses, shopping centres and factories, due to its good strength to weight ratio. The most obvious advantage of timber is that it is a locally available, sustainable material $[5,6]$. It does not need to be mined and subjected to high- energy-demand manufacturing processes that steel and cement require. The energy consumption ratio for timber structures is only $0.76 \mathrm{GJ} / \mathrm{m}^{2}$, whereas for steel structures $-3.24 \mathrm{GJ} / \mathrm{m}^{2}$ and for concrete structures $-2.13 \mathrm{GJ} / \mathrm{m}^{2}$ [30].

A wooden roof or ceiling with glued-laminated timber beams has steel sheeting lying on the beams. This solution may be developed by pouring concrete into the steel sheeting, which improves load-bearing capacity and stiffness of the timber beams. The profiled sheeting may serve as both the formwork and tensile reinforcement. It is possible to save construction materials and construction time, and reduce slab height. Timber-concrete composite structures may be competitive to steel, concrete or steel-concrete composite structures. The aluminium beam and the concrete slab should be joined with shear connectors. The shear connectors used is steel-concrete structures are presented in $[2,13]$. The authors of this article prepared a special connector which consisted of two parts - a headed stud and a wooden screw (see Fig. 1) [28]. It is a new solution.

The idea of timber-concrete composite structures is not new. Schafers and Seim tested timber-concrete composite beams consisting of two glued-laminated timber beams bonded to an ultra-high performance concrete slab using an adhesive [26]. To join a timber beam with a concrete slab it is also possible to use: connection mesh made of surface-untreated waterproof plywood [7], nails, screws, steel plates [17] or anchor connection [10]. 

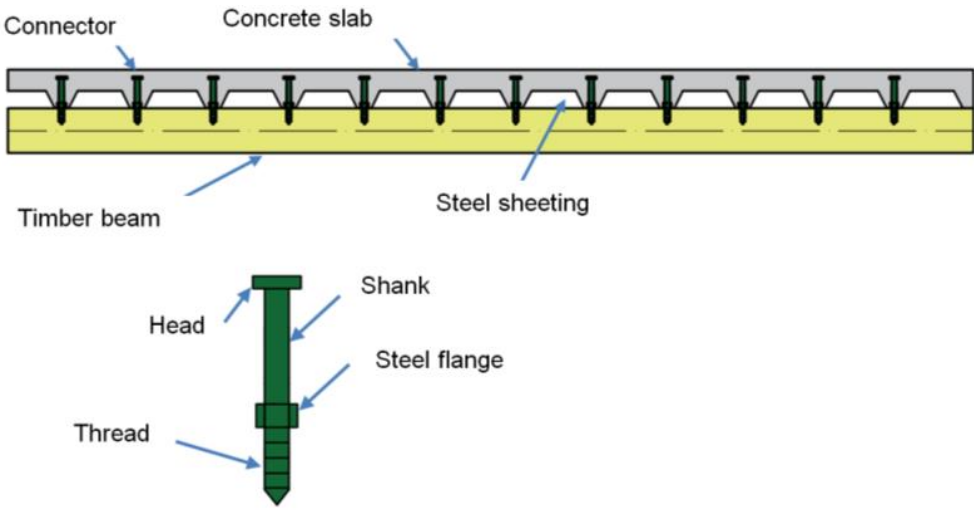

Fig. 1. Connector for timber-concrete composite structures

The preliminary analysis showed that the load-bearing capacity of the bending element increased significantly after joining the beam with the slab. In the preliminary analysis, the authors of this article made an assumption that there was full connection between the timber beam and the concrete slab and they used the plastic method for calculating resistance (see table 1).

Table 1. The plastic bending resistance of the timber-concrete composite beam

\begin{tabular}{|l|l|}
\hline Parameter & Value \\
\hline Dimensions of the cross-section of the timber beam $[\mathrm{cm}]$ & $20.0 \times 30.0$ \\
\hline Glued-laminated timber & GL28h \\
\hline Glued-laminated timber bending resistance $[\mathrm{MPa}]$ & 28.0 \\
\hline Glued-laminated timber tension resistance $[\mathrm{MPa}]$ & 19.5 \\
\hline Tensile force in the timber beam $[\mathrm{kN}]$ & 1170.0 \\
\hline Moment of inertia of the timber beam $I_{y}\left[\mathrm{~cm}^{4}\right]$ & 45000 \\
\hline Section modulus of the timber beam $W_{y}\left[\mathrm{~cm}^{4}\right]$ & 3000 \\
\hline Elastic bending resistance of the timber beam $M_{c, R k}[\mathrm{kNm}]$ & 84.0 \\
\hline Maximum load of the timber beam $2 P[\mathrm{kN}]$ & 98.9 \\
\hline Height of the concrete slab [cm] & 15.0 \\
\hline Width of the concrete slab [cm] & 70.0 \\
\hline Thickness of the concrete part over steel sheeting $[\mathrm{cm}]$ & 9.1 \\
\hline Compressive force in the concrete slab $[\mathrm{kN}]$ & 2057.5 \\
\hline Position of the plastic axis $[\mathrm{cm}]$ & 5.17 \\
\hline Plastic load-bearing capacity $M_{c, p l, R k}[\mathrm{kNm}]$ & 320.7 \\
\hline Maximum load of the composite beam $2 P[\mathrm{kN}]$ & 377.3 \\
\hline
\end{tabular}

The preliminary analysis showed that the load-bearing capacity of the composite beam is four times higher than the load-bearing capacity of the timber beam. However, the load-bearing capacity of the composite beam may be limited by the type of connection and steel sheeting. 
The authors decided to evaluate the impact of the type of steel sheeting on the bending resistance of the timber-concrete composite beam. The concrete slab may be poured into steel sheeting. There are two most often used types of steel sheeting: open trough profiled steel sheets and re-entrant profiled steel sheets [11].

a)

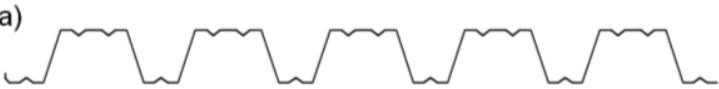

b)

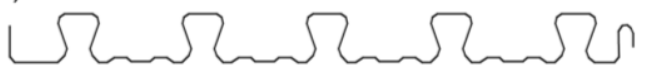

Fig. 2. Types of steel sheets used for composite slabs: a) open trough profiled steel sheets, b) re-entrant profiled steel sheets

The steel sheeting may act as permanent formwork for the concrete slab and through mechanical or frictional interlock may be a part of the composite slab (the sheet provides all, or part, of the main tension reinforcement to the slab). Many composite beams with profiled sheeting are partial composite beams, because of the limitation of the rib width of profiled sheeting. The number of shear connectors of a composite beam with profiled sheeting is in most cases lower than the number required for a full composite design. The additional deflection induced by the shear slip effect at the interface should be taken into consideration $[19,20]$. The tests of steel-concrete composite beams with steel sheeting presented in [20] shown that the degree of shear connection, the arrangement of shear studs, the orientation of the profiled sheeting (placed in a downward position or placed in the upward position) have an impact on the load-bearing capacity and stiffness of the beam. In the composite beams with profiled steel sheeting there may occur horizontal cracks in the concrete troughs near the support of the beams. At the collapse load, the profiled sheeting in the shear span may separate from the concrete, and some shear studs may be broken off. The typical failure modes of the ribs include lateral failure and diagonal failure. Longitudinal cracking may appear due to the longitudinal shear splitting force and transverse cracking at the weaker section of the concrete slab. The transverse cracking may be caused by the local negative moment in the slab resulting from the eccentricity of the longitudinal compression forces. These failure modes may also appear in timber-concrete structures when the concrete slab is poured into the steel sheeting. The authors used the numerical simulation to verify this hypothesis. They analysed two models of timber-concrete composite beams. In the first model, T 55-230-1 open trough profiled steel sheets were used, whereas the second model employed F 59-140-1- re-entrant profiled steel sheets (see Fig. 3). 


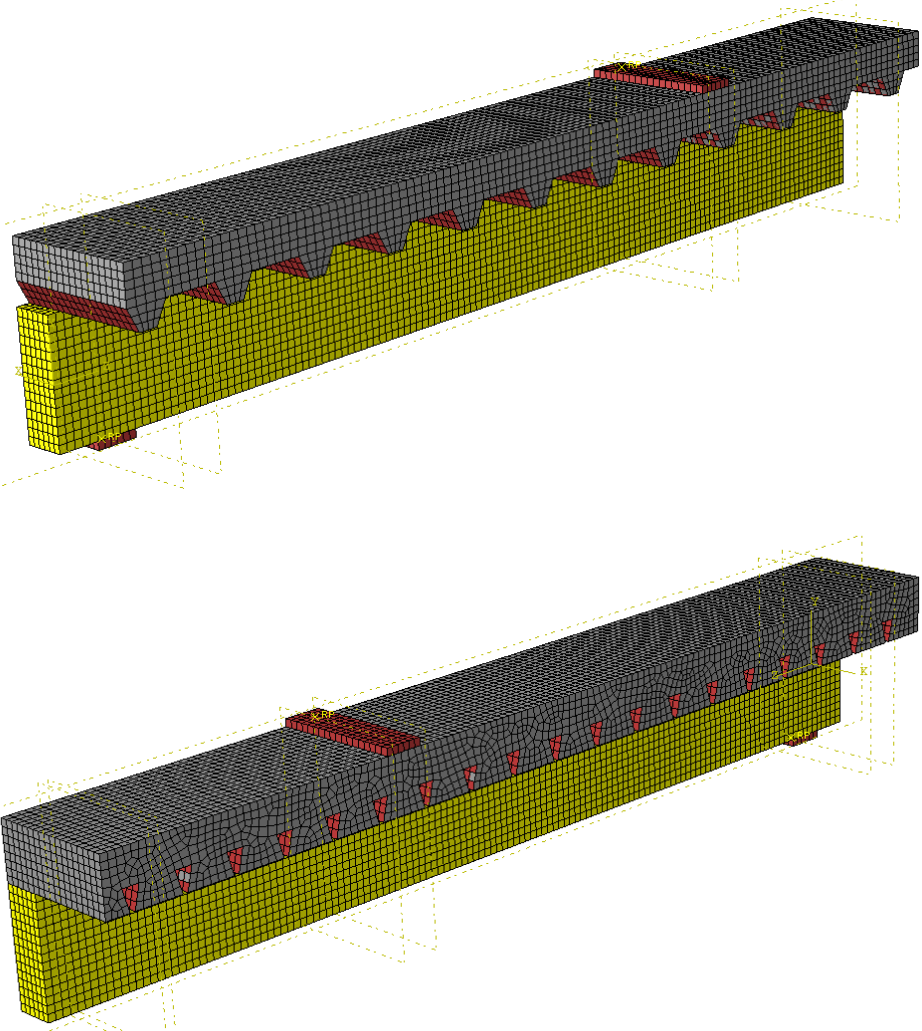

Fig. 3. Analysed models

\section{NUMERICAL ANALYSIS}

The authors of this article analysed 5.1-meter-long timber-concrete composite beams. Numerical models were prepared in the Abaqus program. Calculations were performed using the Newton-Raphson method. The models had two axes of symmetry - for this reason, the authors of this article prepared only $1 / 4$ of each model. The models consisted of a timber beam, a concrete slab and connectors. The cross sections of the timber beams were rectangular (200 $\mathrm{mm} \times 300 \mathrm{~mm}$ ). The timber beams were made of GL28h glued-laminated timber and the concrete slabs were made of $\mathrm{C} 30 / 37$ concrete. The material parameters and dimensions of a single composite beam are presented in table 2 . 
Table 2. Material parameters and dimensions of the composite beam

\begin{tabular}{|l|l|}
\hline Parameter & Value \\
\hline Beam span $L[\mathrm{~m}]$ & 5.1 \\
\hline Height of the concrete slab [cm] & 15.0 \\
\hline Height of the concrete part above the sheeting [cm] & 9.1 \\
\hline Width of the concrete slab [cm] & 70.0 \\
\hline Cross section of the timber beam [cm] & $20.0 \times 30.0$ \\
\hline Material of the timber beam & GL28h \\
\hline Bending strength of the timber [MPa] & 28.0 \\
\hline Tensile strength of the timber [MPa] & 19.5 \\
\hline Compressive strength of the timber [MPa] & 26.5 \\
\hline Concrete & C30/37 \\
\hline Compressive strength of the concrete $f_{c}[\mathrm{MPa}]$ & 38.0 \\
\hline Diameter of the connector [mm] & 19.0 \\
\hline Material of the connector & $\mathrm{S} 235$ \\
\hline Yield strength of the connector [MPa] & 235.0 \\
\hline Steel sheeting in model 1 & $\mathrm{T} \mathrm{55-230-1}$ \\
\hline Steel sheeting in model 2 & F 59-140-1 \\
\hline Thickness of the sheeting [mm] & 1.0 \\
\hline
\end{tabular}

In the first model, open trough profiled steel sheeting was used, whereas in the second model - re-entrant profiled steel sheeting. The concrete was poured into the steel sheeting. The height of the concrete slab was 15.0 to determine the position of the plastic axis above the steel sheeting. Three different materials were taken into account during numerical calculations (see Fig. 4).
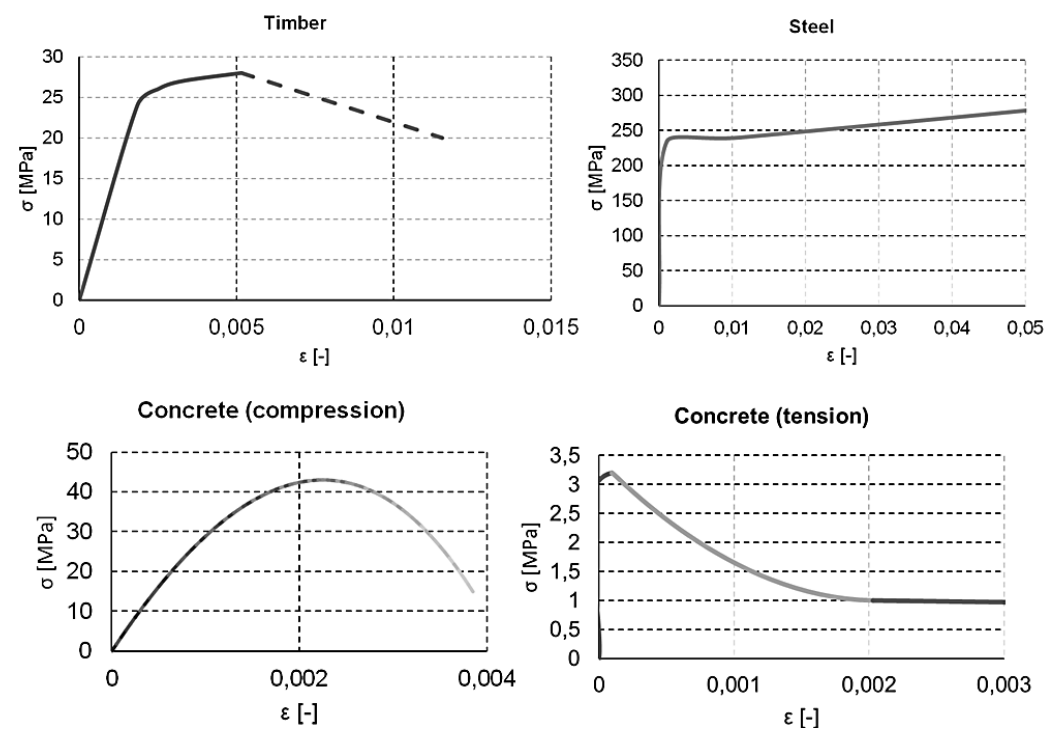

Fig. 4. Stress-strain relations for used materials 
In the numerical calculations, steel was an elastic-plastic material with strain hardening, concrete was an elastic-plastic material with isotropic damage and timber is first behaved as linear elastic material and then as a non-linear elastic material. The parameters of the materials were taken from the standards $[22,23$, $24,25]$. A concrete damaged plasticity model was used for concrete in the Abaqus program, to take into account concrete strength degradation $[12,14,15]$. The load was applied in the form of displacement. The displacement was applied to a flat steel plate just as in a four-point bending test. Thanks to this method of load application, the authors managed to obtain a decrease on the force-deflection diagram and a limited load (load-bearing capacity of the beams). In the FEM model, four types of finite elements were used. The concrete slab and the timber beam were divided into eight-node cuboidal finite solid elements (linear hexahedron type C3D8R). The steel sheeting was modelled as the skin of the concrete slab and it was divided into four-node shell elements (linear quadrilateral type S4R) (see Fig. 5).

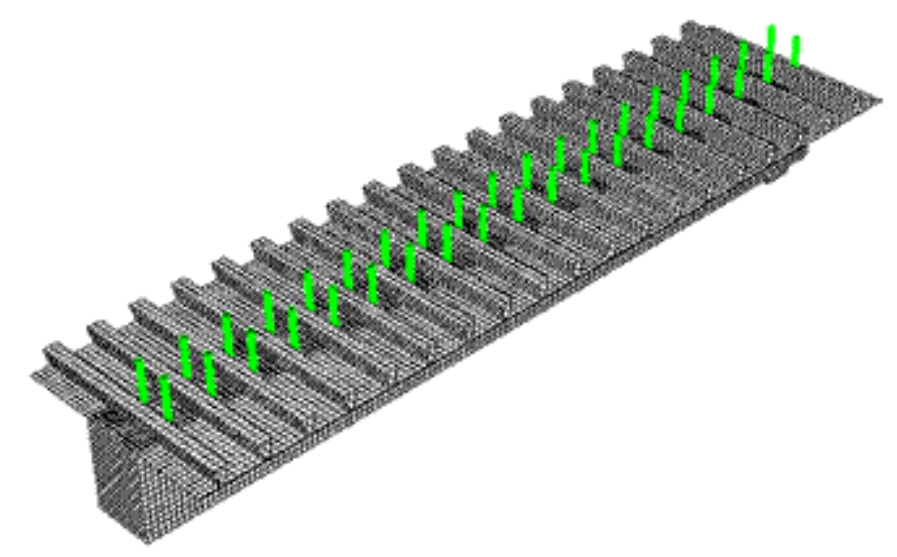

Fig. 5. Timber beam with connectors and steel sheeting as the skin of the concrete slab

The connectors were modelled as wires and divided into beam elements (linear beam type B31). The first part of the connector was embedded in the concrete slab. The second part was embedded in the timber beam. The reinforcement was embedded in concrete and it was divided into truss elements (linear line type T3D2). There was hard contact between the timber beam and the concrete slab. The friction between these elements was also taken into account. The size of the cell was $20 \mathrm{~mm}$. The total number of all the finite elements was about 72000 . 


\section{RESULTS}

As a result of numerical calculations, force-deflection diagrams were obtained (see Fig 6).

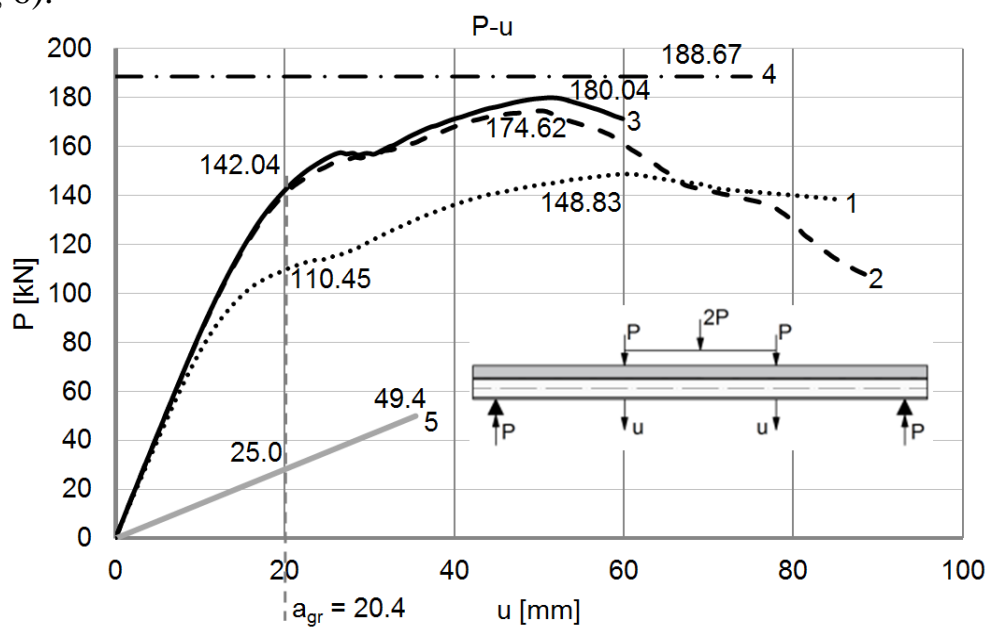

Fig. 6. Force-deflection diagram of analysed beams: 1 - timber-concrete composite beam with open trough profiled steel sheeting, 2 - timber-concrete composite beam with re-entrant profiled steel sheeting, 3 - timber-concrete composite beam with monolithic concrete slab, 4 - plastic load-bearing capacity of timber-concrete composite beam,

$$
5 \text { - timber beam }
$$

The first diagram presents the relations between force $P$ and deflection $u$ for the timber-concrete composite beam with open trough profiled steel sheeting. The maximum load for this beam $\mathrm{P}=148.8 \mathrm{kN}$ was obtained when deflection $\mathrm{a}=60.5$ $\mathrm{mm}$. The maximum load for the timber-concrete composite beam with re-entrant profiled steel sheeting (diagram 2) $\mathrm{P}=174.6 \mathrm{kN}$ was obtained when deflection a $=50.3 \mathrm{~mm}$. There were more connectors in the composite beam with the reentrant steel sheeting, because there were more ribs. The load-bearing capacity obtained using [24] and the plastic method of calculation amounted to $188.7 \mathrm{kN}$. The load-bearing capacity of the timber-concrete composite beams with profiled steel sheeting did not achieve the plastic resistance calculated from [24]. For a better comparison, the numerical analysis was complemented with the calculations where a timber-concrete beam with the monolithic concrete slab was analysed (see Fig. 7).

The load-bearing capacity obtained using numerical calculation for the timberconcrete composite beam with the monolithic concrete slab $(\mathrm{P}=180.0)$ was close to the one obtained using [24] and the plastic method of calculation $(\mathrm{P}=188.7 \mathrm{kN})$. 


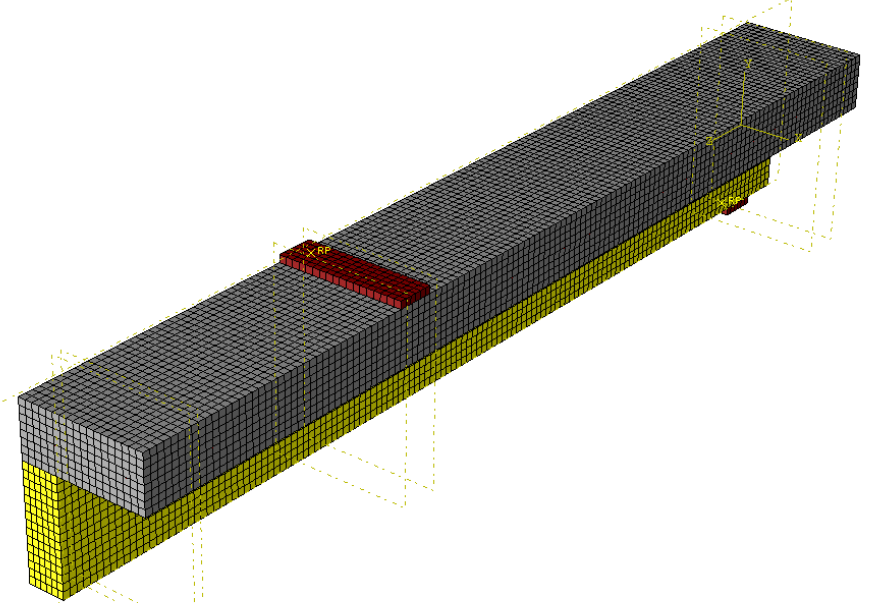

Fig. 7. Timber-concrete composite beam with monolithic concrete slab

Thanks to the concrete damaged plasticity model used in the Abaqus program it was possible to evaluate cracking of the concrete. In the timber-concrete composite beams there were lateral cracks on the top of the concrete slab in the support, and many lateral and diagonal cracks in the ribs (see Fig 8).

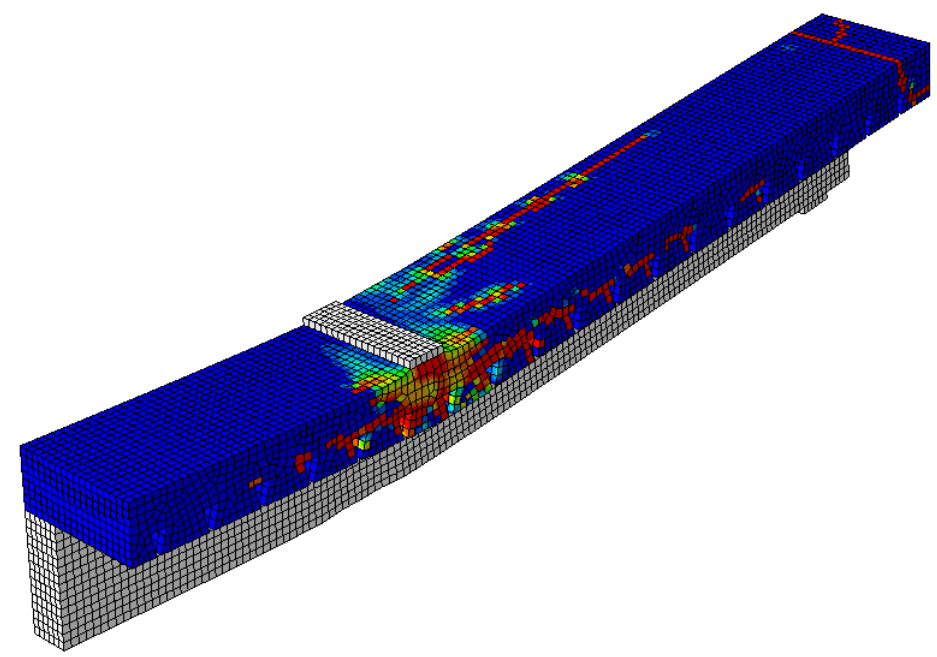

Fig. 8. Cracks in the timber-concrete composite beam with re-entrant profiled steel sheeting 
There was also a lateral crack along the axis of the connectors, connected with their work. These types of failures were also presented in [20]. The number of shear connectors obtained from [24] was required for a full composite design. However, taken into account the form of failures obtained from numerical calculations, the number of shear connectors was lower than the number required for a full composite design. The load-bearing capacity was limited because of the connection.

The authors of this article additionally analysed strains in the cross-section of the composite beams with profiled steel sheeting (see Fig. 9).

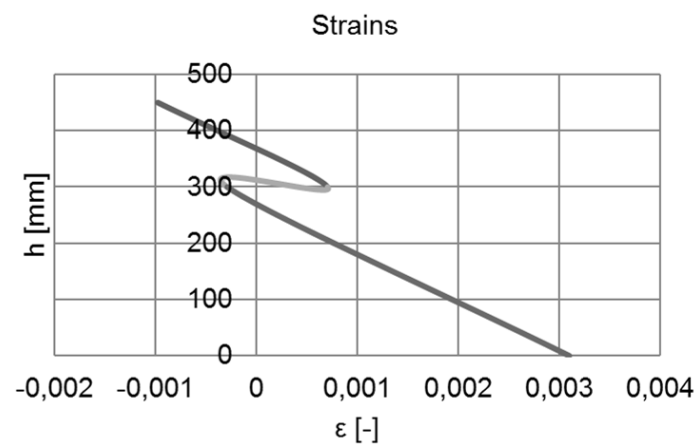

Fig. 9. Strains in the cross-section of the timber-concrete composite beam

The diagram presented in Figure 9 shows that the analysed composite beams with profiled sheeting were partial composite beams, because of the limitation of the rib width of thee profiled sheeting. There was no continuity of displacements at the contact point of the timber beam and the concrete slab. There were two neutral axes in the composite beams. The additional deflection induced by the shear slip effect at the interface caused decreasing of the load-bearing capacity and stiffness. Strain diagrams are non-linear. The flat cross-section hypothesis was impossible to use in the analysed examples.

\section{CONCLUSIONS}

The type of steel sheeting used as a formwork for the concrete slab had an impact on the load-bearing capacity and stiffness of the timber-concrete composite beams. The composite beam with re-entrant profiled steel sheeting had higher load-bearing capacity than the composite beam with open trough profiled steel sheeting. There were more connectors (more ribs) in the composite beam with the re-entrant steel sheeting. The difference between the load-bearing capacity of the timber-concrete composite beam with the monolithic concrete slab and the timber-concrete composite beam with re-entrant profiled steel sheeting was only $5.42 \mathrm{kNm}$. The re-entrant profiled steel sheeting allowed a better cooperation 
between the sheeting and the concrete (when the slab was subjected to bending) than the open trough profiled steel sheeting. The strain diagram showed that the analysed composite beams with profiled sheeting were partial composite beams. The additional deflection induced by the shear slip effect at the interface caused a decrease in the load-bearing capacity and stiffness. Despite the fact that the loadbearing capacity of composite beams with steel sheeting is limited, their use is still advantageous. When the serviceability limit state was taken into account, the maximum load for the timber-concrete beam with the monolithic concrete slab and the timber-concrete composite beam with the re-entrant profiled steel sheeting was almost the same (about $142.0 \mathrm{kN}$ ). The difference between the maximum loads for the timber-concrete composite beam with the re-entrant profiled steel sheeting and the timber-concrete composite beam with open trough profiled steel sheeting was about $30 \mathrm{kN}$ when the serviceability limit state was taken into account. The initial stiffness of the analysed composite beams was the same. Then, when the load was higher than $70.0 \mathrm{kN}$, the stiffness of the timberconcrete composite beam with open trough profiled steel sheeting decreased. The compressive strength of the concrete and the tensile strength of the timber beam was not achieved during the numerical calculations. The load-bearing capacity of the partial composite beams was 3.0 to 3.5 times higher than the loadbearing capacity of the timber beam. When the serviceability limit state was taken into account, the maximum load for the timber-concrete composite beams with the steel sheeting was 4 to 6 times higher than the maximum load for the timber beam.

To verify the aforementioned results, laboratory tests are necessary. More problems connected with timber-concrete composite structures remain to be solved, e.g. the one related to the behaviour of timber subjected to long-term load.

\section{REFERENCES}

1. Radomski W.: Research and bridge applications of high-performance lightweight concrete in Poland, in: Proceedings of the 4th International Conference on Current and Future Trends in Bridge Design, Construction and Maintenance, Kuala Lumpur 10-11 October 2005, 402-411.

2. Biegus A., Lorenc W.: Development of shear connections in steel-concrete composite structures, Civil And Environmental Engineering Reports, 15, 4 (2014) 23-32.

3. Chybiński M., Garstecki A.: Diagonal versus orthogonal ribs in stability of steel I beams, Procedia Engineering, 172 (2017) 172-177.

4. Ciesielczyk K., Studziński R.: Experimental and numerical investigation of stabilization of thin-walled Z-beams by sandwich panels, Journal of Constructional Steel Research, 133 (2017) 77-83. 
5. Czarnecki L., Kaproń M., Piasecki M., Wall S.: Budownictwo zrównoważone budownictwem przyszłości, Inżynieria i Budownictwo, 68, 1 (2012) 18-21.

6. Czarnecki L., Kaproń M.: Ocena środowiskowa budynków a zrównoważone budownictwo, Zeszyty Naukowe Politechniki Rzeszowskiej. Budownictwo i Inżynieria Środowiska, 59, 3/12/III (2012) 301-314.

7. Dankova J., Mec P., Majstrikova T.: Stiffness analysis of glued connection of the timber-concrete structure, Open Engineering, 6 (2016) 241-249.

8. Denisiewicz A., Kuczma M.: Two-Scale Modelling of Reactive Powder Concrete. Part III: Experimental Tests and Validation, Engineering Transactions, 63, 1, 55-76, 2015.

9. Dolejs J., Tunega I., Hatlman V.: Experiments with high performance steel and composite members, Zeszyty Naukowe Politechniki Rzeszowskiej. Budownictwo i Inżynieria Środowiska, 52, 264 (2009) 33-42.

10. Gutkowski R., Brown K., Shigidi A., Natterer J.: Laboratory tests of composite wood-concrete beams, Construction and Building Materials, 22 (2008) 1059-1066.

11. Hicks S., Composite slabs, Dissemination of information workshop, Brussels 18-20 February 2008.

12. Kmiecik P., Kamiński M., Modelling of reinforced concrete structures and composite structures with concrete strength degradation taken into consideration, Archives of Civil and Mechanical Engineering, 11, 3 (2011) 623-636.

13. Kozioł P., Kożuch M., Lorenc W., Rowiński S.: Innovative solution of transition zone in steel-concrete hybrid beam, in: Recent Progress in steel and composite structures, edit. M. Giżejowski, A. Kozłowski, J. Marcinowski, J. Ziółko, CRC Press-Taylor \& Francis Group 2016.

14. Jankowiak I., Analysis of RC beams strengthened by CFRP strips Experimental and FEA study, Archives of Civil and Mechanical Engineering, 12, 3 (2012) 376-388.

15. Jankowiak I., Madaj A., Load carrying capacity of RC beams strengthened by pre-tensioned CFRP strips, in: Recent advances in computational mechanics: proceedings of the 20th International Conference on Computer Methods in Mechanics (CMM 2013), Poznań, 27-31 August, 2013, edit. T. Łodygowski, J. Rakowski, P. Litewka, CRC Press 2014.

16. Jasiczak J., Wdowska A., Rudnicki T.: Betony ultrawysokowartościowe właściwości, technologie, zastosowania, Stowarzyszenie Producentów Cementu, Kraków 2008.

17. Łukaszewska E., Johnsson H., Fragiacomo M., Performance of connections for prefabricated timber-concrete composite floors, Materials and Structures, 41 (2008) 1533-1550. 
18. Moody R., Hernandez R.: Glued-Laminated Timber, in: Engineered wood products - A guide for specifiers, designers and users, edit. S. Smulski, PFS Research Foundation 1997, 1-39.

19. Nie J., Cai C.S.: Steel-Concrete Composite Beams Considering Shear Slip Effects, Journal of Structural Engineering, 129, 4 (2003) 495-506.

20. Nie J., Cai C.S., Wang T.: Stiffness and capacity of steel-concrete composite beams with profiled sheeting, Engineering Structures, 27 (2005) 1074-1085.

21. Pawłowski D., Szumigała M.: Flexural behaviour of full-scale basalt FRP RC beams - experimental and numerical studies, Procedia Engineering, 108 (2015) 518-525.

22. PN-EN 1992-1-1, Projektowanie konstrukcji betonowych. Część 1-1: Reguły ogólne i reguły dla budynków.

23. PN-EN 1993-1-1, Projektowanie konstrukcji stalowych. Część 1-1: Reguły ogólne i reguły dla budynków.

24. PN-EN 1994-1-1, Projektowanie konstrukcji zespolonych stalowobetonowych - Część 1-1: Reguły ogólne i reguły dla budynków.

25. PN-EN 1995-1-1, Projektowanie konstrukcji drewnianych. Część 1-1: Reguły ogólne i reguły dla budynków.

26. Schafers M., Werner S.: Investigation on bonding between timber and ultrahigh performance concrete (UHPC), Conctruction and Buiding Materials, 25, 7 (2011) 3078-3088.

27. Szewczak I., Rzeszut K.: Pilotażowe badania eksperymentalne cienkościennych belek stalowych typu sigma wzmocnionych taśmami CFRP, Materiały Budowlane, 11 (2016) 84-85.

28. Szumigała E., Szumigała M., Polus Ł.: A numerical analysis of the resistance and stiffness of the timber and concrete composite beam, Civil And Environmental Engineering Reports, 15, 4 (2014) 139-150.

29. Szumigała M., Polus Ł.: Applications of aluminium and concrete composite structures, Procedia Engineering, 108 (2015) 544-549.

30. Żurawski J.: Szkoła projektowania, Cz. 1, Projektowanie zrównoważone, Izolacje, 1, 15 (2010) 96-98.

\section{ANALIZA NOŚNOŚCI BELEK ZESPOLONYCH DREWNIANO-BETONOWYCH Z PŁYTĄ BETONOWĄ NA BLASZE FAŁDOWEJ}

\section{Streszczenie}

Analizie poddano belki zespolone drewniano-betonowe składające się z prostokątnej belki drewnianej oraz płyty betonowej wylanej na blasze fałdowej. Współpracę belki z płytą zapewniają specjalne stalowe łączniki, które są przedmiotem zgłoszenia 
patentowego. W referacie przedstawiono wyniki analiz numerycznych dotyczących wpływu rodzaju stalowych blach fałdowych, na których wykonywane są płyty żelbetowe współpracujące z drewnianymi belkami. Okazuje się, że rodzaj blachy fałdowej służącej jako deskowanie i jako element mogący współpracować z betonową płytą, ma istotny wpływ nie tylko na wytrzymałość samej płyty, ale również na nośność i sztywność belki zespolonej drewniano-betonowej

Słowa kluczowe: konstrukcje zespolone drewniano-betonowe, belki zespolone, MES, Abaqus

Editor received the manuscript: 09.092017 